\title{
Global distributions of acetone in the upper troposphere from MIPAS spectra
}

\author{
D. P. Moore ${ }^{1}$, J. J. Remedios ${ }^{1}$, and A. M. Waterfall ${ }^{2}$ \\ ${ }^{1}$ Earth Observation Science Group, Department of Physics and Astronomy, University of Leicester, University Road, \\ Leicester, UK \\ ${ }^{2}$ STFC Rutherford Appleton Laboratory, Didcot, UK
}

Correspondence to: D. P. Moore (dpm9@le.ac.uk)

Received: 30 July 2010 - Published in Atmos. Chem. Phys. Discuss.: 11 October 2010

Revised: 21 December 2011 - Accepted: 5 January 2012 - Published: 17 January 2012

\begin{abstract}
This study reports the first global measurements of acetone $\left(\mathrm{C}_{3} \mathrm{H}_{6} \mathrm{O}\right)$ in the upper troposphere (UT). Profiles were obtained between $9 \mathrm{~km}$ and $15 \mathrm{~km}$ from measurements made by the Michelson Interferometer for Passive Atmospheric Sounding (MIPAS) onboard Envisat in August 2003. Errors per profile are lower than $40 \%$ between $180 \mathrm{hPa}$ and $350 \mathrm{hPa}$. We report strong hemispheric differences in the acetone volume mixing ratios (VMRs), with average concentrations highest in the Northern Hemisphere (NH) mid-latitude UT, between 1000 pptv and 1600 pptv with maxima up to $2300 \mathrm{pptv}$. Our results show a strong enhancement of acetone relative to $\mathrm{CO}$, particularly over Europe $\left(7 \mathrm{pptv}_{\mathrm{ppbv}}{ }^{-1}\right)$, confirming aircraft studies. Tenday backward trajectories from these high European values show strong contributions from air flows over North America (56\%) and $25 \%$ from Southernmost Asia. Enhanced acetone is also observed over Greenland, Siberia and biomass burning regions of Africa. Zonal distributions show that acetone VMRs decrease rapidly with increasing altitude (decreasing pressure), particularly in the $\mathrm{NH}$. Poleward of $45^{\circ} \mathrm{S}$, acetone VMRs remain fairly consistent with average VMRs between 400 pptv and 500 pptv. In 5 -day averages at $9 \mathrm{~km}, \mathrm{NH}$ VMRs poleward of $45^{\circ} \mathrm{N}$ are consistently higher than Southern Hemisphere observations poleward of $45^{\circ} \mathrm{S}$, by between $750 \mathrm{pptv}$ and $1100 \mathrm{pptv}$. The results show a clear influence of mid-latitude and transport processes on the acetone summertime distribution.
\end{abstract}

\section{Introduction}

Acetone $\left(\mathrm{C}_{3} \mathrm{H}_{6} \mathrm{O}\right)$ is present ubiquitously in the troposphere with concentrations in the range $0.2 \mathrm{ppb}$ to $3 \mathrm{ppb}$ as determined from sporadic aircraft measurements (Jacob et al., 2002; Arnold et al., 1997; Knop and Arnold, 1987) and is a major source of hydrogen oxide radicals $\left(\mathrm{HO}_{\mathrm{x}}\right)$ and peroxyacetyl nitrate (PAN) in the upper troposphere (UT) (Singh et al., 1995; Jaegle et al., 1997, 2001; McKeen et al., 1997; Wennberg et al., 1998; Collins et al., 1999; Muller and Brasseur, 1999). Elevated levels of $\mathrm{HO}_{\mathrm{x}}$ imply a more photochemically active UT, with enhanced rates of ozone formation, and has implications for the mediation of ozone in low water vapour (less than $100 \mathrm{ppmv}$ ) conditions (Folkins and Chatfield, 2000).

The presence of acetone in the upper troposphere was originally detected by the Max-Planck-Institut für Kernphysik Heidelberg group (Hauck and Arnold, 1984; Knop and Arnold, 1987) and more recent aircraft campaigns (such as Scheeren et al., 2003; de Reus et al., 2003) have added to the number of measurements of acetone in the UT. Within the last few years, more regular montoring of acetone in the atmosphere has been achieved by the CARIBIC (Civil Aircraft for the Regular Investigation of the atmosphere Based on an Instrumental Container) program (Brenninkmeijer et al., 2007). Sprung and Zahn (2010) use CARIBIC data to show that a strong seasonal variation of acetone occurs at the midlatitude tropopause with a maxima of $900 \mathrm{pptv}$ in summer and 200 pptv in winter. A study by Elias et al. (2011) found satisfactory agreement between CARIBIC acetone and the 
LMDz-INCA chemistry-climate model although the measurements displayed far more real variability than the model results. The measured acetone volume mixing ratio (VMR) was found to vary by more than $1000 \mathrm{pptv}$ within only 5 latitude-longitude degrees in summertime.

Main sources of acetone include atmospheric oxidation of precursor hydrocarbons (propane, isobutane, and isobutene), biomass burning and direct biogenic emissions with a small percentage from primary anthropogenic emission (Singh et al., 1994; Arnold et al., 1997; Crutzen et al., 2000). Importantly, the sources are still poorly understood (Jacob et al., 2002). The main sinks of acetone include photolysis and reaction with $\mathrm{OH}$ radicals and this results in an estimated global mean lifetime for acetone of the order of a month (Gierczak et al., 1998). Another sink mechanism that has been proposed is deposition to the oceans (Singh et al., 1994).

The advent of spaceborne limb-viewing Fourier transform spectrometers, with high spectral resolution, has allowed the possibility to distinguish lines of weakly absorbing species from stronger absorbers such as carbon dioxide in the upper troposphere and lower stratosphere (UTLS). One such instrument, which measures limb-emission, is the Michelson Interferometer for Passive Atmospheric sounding (MIPAS) onboard the ENVIronmental SATellite (Envisat) (Fischer et al., 2008; Fischer and Oelhaf, 1996). Operationally generated data sets from the MIPAS consist of temperature, $\mathrm{H}_{2} \mathrm{O}, \mathrm{O}_{3}, \mathrm{CH}_{4}, \mathrm{~N}_{2} \mathrm{O}, \mathrm{HNO}_{3}$, and $\mathrm{NO}_{2}$ profiles although the high-spectral resolution of the data $\left(0.035 \mathrm{~cm}^{-1}\right.$ unapodized $)$ allows the potential retrieval of many other minor gas species (Burgess et al., 2004; Hoffmann et al., 2005; von Clarmann et al., 2006).

We expand on previous work by Remedios et al. (2007a), which presented a detection of atmospheric acetone using the balloon version of the MIPAS to show the first global measurements of acetone VMRs in the UTLS. We present data from August 2003 alongside an analysis of the errors and sensitivity study of Envisat MIPAS spectra to acetone. We also present results investigating the global relationship between acetone and carbon monoxide (CO).

\section{Measurements}

The MIPAS instrument onboard Envisat was successfully launched in March 2002 as part of an ambitious and innovative payload. The Envisat is in a polar orbit at an altitude of $800 \mathrm{~km}$, with an orbital period of about $100 \mathrm{~min}$ and a reference orbit repeat cycle of 35 days. The MIPAS (Fischer and Oelhaf, 1996; Fischer et al., 2008) is a Fourier Transform Spectrometer that provides continual limb emission measurements in the mid infrared over the range $685 \mathrm{~cm}^{-1}$ to $2410 \mathrm{~cm}^{-1}$ ( $14.6 \mu \mathrm{m}$ to $\left.4.15 \mu \mathrm{m}\right)$ at an unapodized resolution of $0.035 \mathrm{~cm}^{-1}$ during the first two years of measurements. Due to MIPAS slide mirror problems during oper- ation, the instrument has operated in two distinct measurement modes referred to as "full-resolution" and "optimisedresolution". This paper concentrates on measurements from the full spectral resolution period of MIPAS; the instrument subsequently operated in a reduced spectral mode from $\mathrm{Au}-$ gust 2004 onwards. The instrument's field of view is approximately $3 \mathrm{~km}$ (vertical) $\times 30 \mathrm{~km}$ (horizontal) and one complete limb sequence of measurements in the full-resolution nominal mode consisted of 17 spectra with tangent altitudes at $68 \mathrm{~km}, 60 \mathrm{~km}, 52 \mathrm{~km}, 47 \mathrm{~km}, 42 \mathrm{~km}$ and continuing downwards to $6 \mathrm{~km}$ in $3 \mathrm{~km}$ intervals.

The acetone spectral reference data used in the work came from a set of infrared absorption cross-sections measured at the Molecular Spectroscopy Facility at the Rutherford Appleton Laboratory and described in Waterfall (2004). In the work, a set of temperature and pressure dependent absorption cross-sections were derived covering a temperature range between $298 \mathrm{~K}$ and $214 \mathrm{~K}$. Measurements were recorded at a spectral resolution of approximately $0.03 \mathrm{~cm}^{-1}$ (defined as 0.9/optical pathlength) and Norton-Beer strong apodization. For the $v_{7}\left(\mathrm{C}-\mathrm{C}\right.$ stretch) acetone band (between $1195 \mathrm{~cm}^{-1}$ and $1240 \mathrm{~cm}^{-1}$ ), these measurements have been estimated to have total errors varying between $4 \%$ and $10 \%$ depending on the frequency and the temperature. Recent work by Harrison et al. (2010) determined absorption cross sections for acetone in a similar spectral range to Waterfall (2004) but extending their measurements down to $194 \mathrm{~K}$. Their estimated uncertainty on the cross-sections of $4 \%$ gives confidence that our error estimate is conservative.

The presence of acetone spectral signatures in MIPAS spectra was demonstrated by Remedios et al. (2007a) from a balloon-borne version of the instrument. Using data collected from a flight on 8 May 1998 near Aire sur l'Adour, Remedios et al. (2007a) were able to infer an abundance of $530 \mathrm{pptv}$ of acetone at $10.4 \mathrm{~km}$, using a band at $1218 \mathrm{~cm}^{-1}$. The MIPAS on Envisat has a similar performance to the balloon-borne instrument except that the satellite instrument only observes the acetone band used by Remedios et al. (2007a) above $1215 \mathrm{~cm}^{-1}$ due to a gap in the detector range. In this work, we choose a narrower microwindow selected between $1216.75 \mathrm{~cm}^{-1}$ and $1217.5 \mathrm{~cm}^{-1}$.

\subsection{Radiance simulations}

Figure 1 shows the mid-latitude contribution of acetone to the limb radiance at $9 \mathrm{~km}$ over an extended $1215 \mathrm{~cm}^{-1}$ to $1230 \mathrm{~cm}^{-1}$ spectral range (Fig. 1a) and the retrieval microwindow (Fig. 1b) calculated using the Oxford reference forward model (RFM). The RFM is a line-by-line radiative transfer model, derived from the Genln2 model (Edwards, 1992), with the ability to simulate infra-red spectra given the calculated or measured instrument field-of-view, lineshapes, spectroscopic parameters and atmospheric climatology profiles (see http://www.atm.ox.ac.uk/RFM/ for further details). Profiles for pressure, temperature and all interfering gases, 


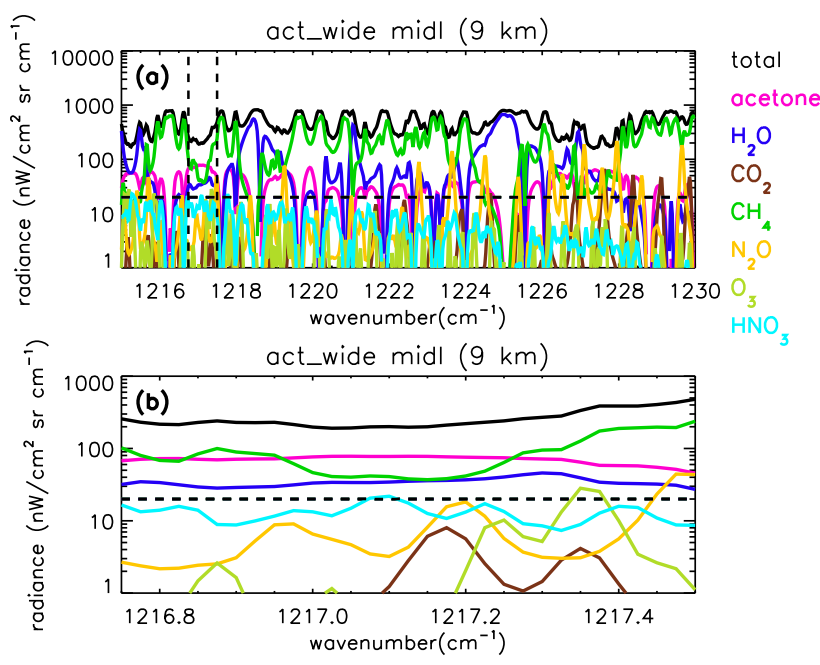

Fig. 1. Plot of modelled radiance contributions for the radiatively active gases in (a) the $1215 \mathrm{~cm}^{-1}$ to $1230 \mathrm{~cm}^{-1}$ range and (b) $1216.75 \mathrm{~cm}^{-1}$ to $1217.5 \mathrm{~cm}^{-1}$ in the mid-latitudes $\left(20^{\circ}\right.$ to $\left.65^{\circ}\right)$. The dotted line represents the noise equivalent spectral radiance (NESR) of $20 \mathrm{nW} /\left(\mathrm{cm}^{2} \mathrm{sr} \mathrm{cm}^{-1}\right)$ as reported in MIPAS band-B by Kleinert et al. (2007).

except acetone, were taken from the version 3.1 mid-latitude day reference atmospheres of Remedios et al. (2007b). The acetone profile used in this simulation was taken from the MOZART model (Horowitz et al., 2003) and is representative of Northern Hemisphere (NH) mid-latitude conditions during summer. Values decrease from approximately $738 \mathrm{pptv}$ at $9 \mathrm{~km}$ to $65 \mathrm{pptv}$ by $15 \mathrm{~km}$. The $v_{7} \mathrm{C}-\mathrm{C}$ stretch at $1216 \mathrm{~cm}^{-1}$ is observable according to radiative transfer simulations at $9 \mathrm{~km}$ and $12 \mathrm{~km}$ (not shown) above the MIPAS band B noise equivalent spectral radiance (NESR). By $15 \mathrm{~km}$, the signal decreases rapidly, so we may only expect to measure acetone (and not reproduce just the a priori) where there is a significant enhancement of acetone compared to the background (i.e. in a biomass burning event).

\subsection{Retrieval approach}

Acetone VMR retrievals have been achieved using the MIPAS Orbital Retrieval using Sequential Estimation (MORSE), a FORTRAN77 program developed by the University of Oxford (http://www.atm.ox.ac.uk/MORSE/). The scheme uses a sequential estimation approach to determine the most probable solution consistent with both the measurements and the a priori information. In the retrieval scheme, acetone is retrieved jointly with background continuum. However, the background continuum is constrained to low values typical of the cloud-free scenes analysed here; acetone retrieved shows no correlation with continuum values. All trace gas retrievals are performed in log space.

As the MIPAS instrument makes $m$ radiance measurements (y) at many different limb altitudes a set of $n$ parame- ters (the state vector $\boldsymbol{x}$ ) can be determined from this set of measurements. The optimal estimation retrieval approach (Rodgers, 2000) aims to gain as much information about $\boldsymbol{x}$ given $\mathbf{y}$. This approach provides a linearized form for an estimate of $\hat{\boldsymbol{x}}$ (the atmospheric profile) that is based on a prior estimate $\boldsymbol{x}_{\mathrm{a}}$ of the state and the set of measurements from the instrument:

$\hat{\boldsymbol{x}}=\mathbf{G y}+\left(\mathbf{I}_{n}-\mathbf{G K}\right) \mathbf{x}_{\mathrm{a}}$

where $\mathbf{K}$ is the Jacobian matrix $\left(\mathrm{K}_{i, j}=\partial \mathrm{y}_{i} / \partial \mathrm{x}_{j}\right)$ and $\mathbf{G}$ is the gain matrix given by:

$\mathbf{G}=\mathbf{S}_{\mathrm{a}} \mathbf{K}^{T}\left(\mathbf{S}_{y}+\mathbf{K} \mathbf{S}_{\mathrm{a}} \mathbf{K}^{T}\right)^{-1}$

$\mathbf{S}_{\mathrm{a}}$ is the covariance of $\boldsymbol{x}_{\mathrm{a}}$ about the exact state and $\mathbf{S}_{y}$ the covariance of $\mathbf{y}$ about the perfect measurements that would arise from the exact state. Due to the large seasonal and spatial variability of acetone estimated from the TOMCAT model (N. Richards, personal communication, 2010) and observed in aircraft measurements (T. Schuck, personal communication, 2010) $\mathbf{S}_{\mathrm{a}}$ was set at $(300 \%)^{2}$ for acetone. For $\mathbf{S}_{\mathrm{a}}$, the off-diagonal elements were determined by a first order auto-regressive model with a vertical correlation length of $6 \mathrm{~km}$. The off-diagonal elements of $\mathbf{S}_{y}$ were set to zero (assuming no noise correlation between different altitudes).

The Levenberg-Marquardt iteration technique was used to find the best estimate of the state, $\hat{\mathbf{x}}$. The matrices $\mathbf{S}_{\mathrm{a}}$ and $\mathbf{S}_{y}$ are inverted using the Gauss-Jordan Elimination technique with full-pivoting, based on the routine GAUSSJ given on 28-29 of Numerical Recipes (Press et al., 1992).

$$
\begin{aligned}
\mathbf{x}_{i+1}= & \mathbf{x}_{i}+\left[(1+\gamma) \mathbf{S}_{\mathrm{a}}^{-1}+\mathbf{K}_{i}^{T} \mathbf{S}_{y}^{-1} \mathbf{K}_{i}\right]^{-1} \\
& \left\{\mathbf{K}_{i}^{T} \mathbf{S}_{y}^{-1}\left[\mathbf{y}-\mathbf{F}\left(\mathbf{x}_{i}\right)\right]-\mathbf{S}_{\mathrm{a}}^{-1}\left[\mathbf{x}_{i}-\mathbf{x}_{\mathrm{a}}\right]\right\}
\end{aligned}
$$

where $\mathbf{F}$ is the RFM modelled radiance at instrument spectral resolution with vertical field-of-view convolution.

The scheme uses the full retrieval state vector from the beginning, with measurements from each tangent altitude incorporated sequentially rather than with one large matrix. As the measurements are assumed uncorrelated between different tangent heights or different microwindows, mathematically the solution is identical as if all measurements were used at once.

The value of $\gamma$ in Eq. (3). is initialised to a value of one. If the chi-square parameter reduces, the new state vector, $\boldsymbol{x}_{i+1}$, is accepted and $\gamma$ is divided by ten. If the error increases on $\boldsymbol{x}_{i+1}$ then $\gamma$ is multiplied by ten and Eq. (3). is solved again. This process is repeated until the chi-square is reduced below a 1.5 threshold and the difference between consecutive chisquare values is less than 0.2 . The chi-square values (which contain a priori and radiance components) were chosen based on tests for selected orbits which attempted to optimise the speed of the retrieval (i.e. minimize the number of iterations) without losing accuracy in the retrieved data. In successful 
retrievals, the scheme generally converges within 3 to 4 iterations.

Due to the long horizontal path of each MIPAS measurement, clouds are likely to contaminate many tropospheric observations and appear in the instrument field-of-view. By using a simple ratio approach and computing a ratio between the mean radiance in the $788.20 \mathrm{~cm}^{-1}$ to $796.25 \mathrm{~cm}^{-1}$ and $832.30 \mathrm{~cm}^{-1}$ to $834.40 \mathrm{~cm}^{-1}$ spectral bands (Spang et al., 2004) it is possible to distinguish clouds in MIPAS spectra. We used a cloud threshold value of 4 and in cases where the ratio is below this value, the measurements at this altitude, and all altitudes below, were flagged as cloudy and no retrieval performed on the sweeps.

As shown in Fig. 1, the acetone microwindow has several other interfering species. To minimize the errors on acetone retrievals, data for pressure/temperature (jointly), water vapour, ozone $\left(\mathrm{O}_{3}\right)$, nitric acid $\left(\mathrm{HNO}_{3}\right)$, methane $\left(\mathrm{CH}_{4}\right)$ and nitrous oxide $\left(\mathrm{N}_{2} \mathrm{O}\right)$ were pre-retrieved from MORSE, for each sweep, before we retrieve acetone VMRs. All other species were taken from the reference atmospheres of Remedios et al. (2007b). We restricted the acetone retrieval altitude range from $6 \mathrm{~km}$ to $21 \mathrm{~km}$ and for pre-retrieved species this extends between $6 \mathrm{~km}$ and $68 \mathrm{~km}$. The apodized instrument line-shape (AILS) data are based on pre-flight estimates (H. Nett, pers. comm., 2003) with line parameters and absorption cross-sections of interfering gases taken from HITRAN 2004 with updates up to the end of 2008 applied (Rothman et al., 2005). More details of the spectroscopy updates can be found at www.hitran.com.

\subsection{Error analysis}

A detailed error analysis for acetone is shown in Fig. 2 for four separate latitude bands - tropical $\left(20^{\circ} \mathrm{S}\right.$ to $\left.20^{\circ} \mathrm{N}\right)$, midlatitudes $\left(20^{\circ}\right.$ to $65^{\circ}$ in each Hemisphere), polar summer $\left(65^{\circ}\right.$ to $90^{\circ}$ in the summer Hemisphere) and polar winter $\left(65^{\circ}\right.$ to $90^{\circ}$ in the winter Hemisphere). Both the random retrieval noise and systematic errors (model parameter, gain, instrument line shape and spectroscopy) are shown along with the total error.

Firstly, the systematic model parameter errors were calculated using measured biases in MIPAS data. An uncertainty of $20 \%$ has been indicated for MIPAS water vapour (Lahoz et al., 2004), $10 \%$ for ozone (Cortesi et al., 2007), $10 \%$ for nitric acid (Wang et al., 2007), $5 \%$ for methane (Payan et al., 2009) and $4 \%$ for nitrous oxide (Payan et al., 2009). Uncertainties of $1 \mathrm{~K}$ for temperature (Ridolfi et al., 2007) and $4 \%$ for pressure (Raspollini et al., 2006) were used. The error for the other contaminants was expected to be small; assumed at $10 \%$ for each. The errors due to uncertainties in these gases were likely to be lower in the real measurements than calculated here. Comparison of operational products and our retrieved data (not shown) is excellent with only very small differences for upper tropospheric temperature, less than $1 \mathrm{~K}$ in the global monthly average, water vapour
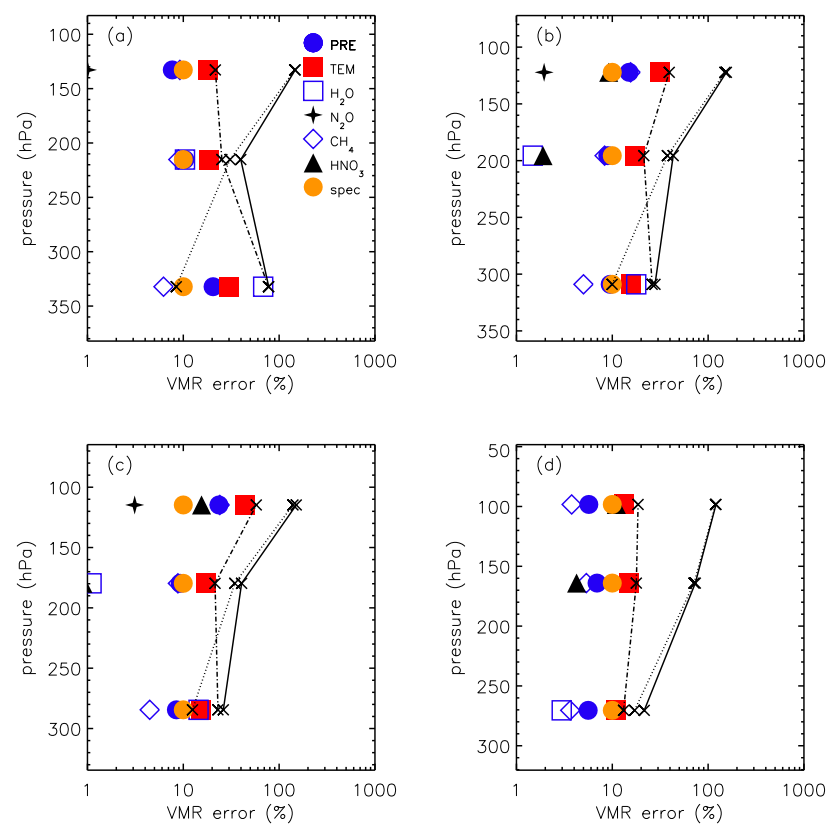

Fig. 2. Error budget for acetone VMR retrievals. The data have been split into regimes, (a) $20^{\circ} \mathrm{S}$ to $20^{\circ} \mathrm{N}$ - tropical, (b) 20 to $65^{\circ}$ - mid-latitudes, (c) 65 to $90^{\circ}$ in the summer hemisphere - polar summer, (d) 65 to $90^{\circ}$ in the winter hemisphere - polar winter. The solid black line represents the total error on a single retrieval. The random (dotted) and systematic (dashed) component of the error are also shown. Systematic errors are dominated by pressure ("PRE") and temperature ("TEM"), acetone spectroscopy ("SPEC"), and gain uncertainties.

less than 2 ppmv and better than $10 \%$ for methane. The uncertainty of the instrument gain and instrument offset were taken to be $2 \%$ and $2 \mathrm{nW} /\left(\mathrm{cm}^{2} \mathrm{sr} \mathrm{cm}^{-1}\right)$, respectively (Spang et al., 2005). For the $1216.75 \mathrm{~cm}^{-1}$ to $1217.5 \mathrm{~cm}^{-1}$ spectral range, we note that the spectroscopic errors on the individual cross-sections are estimated to range between $5 \%$ to $7 \%$. An additional source of error may be introduced within the radiative transfer model when extrapolating the data to the appropriate atmospheric conditions, and a more conservative estimate of $10 \%$ has been used in the calculation of the retrieval error detailed later in this paper. This estimate also accounts for cases where the temperature of the measurement is less than $214 \mathrm{~K}$ (the lowest temperature at which the acetone cross-sections were measured). This is particularly relevant for tropical acetone retrievals where it was found that $32 \%$ (1199 out of 3737 cases) had a temperature of less than $214 \mathrm{~K}$ in the upper troposphere.

The total error on a single retrieved VMR is calculated to be generally below $40 \%$ at pressures between $180 \mathrm{hPa}$ and $350 \mathrm{hPa}$, although the water vapour contamination in the tropics limits errors to approximately $80 \%$. At pressures lower than $180 \mathrm{hPa}$, the random retrieval error component increases rapidly in all regions and the total error on a single 


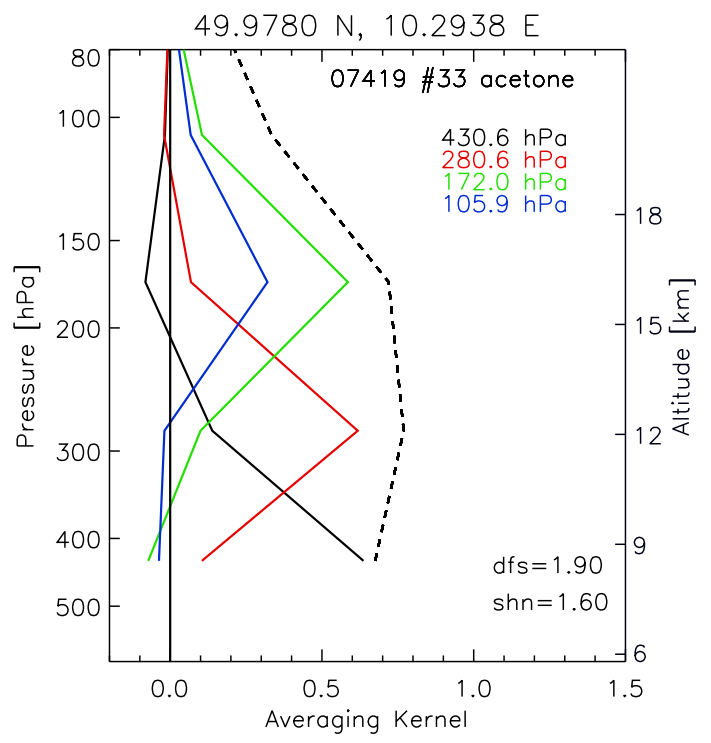

Fig. 3. A representative averaging kernel in $\log (\mathrm{VMR})$ for a single mid-latitude acetone retrieval from orbit 07419 , scan number 33 (1 August $\left.2003,50.0^{\circ} \mathrm{N}, 10.3^{\circ} \mathrm{E}\right)$. There are 1.9 degrees of freedom for these measurements. For this particular scan, the measurements have 1.6 bits of Shannon information content. The dashed black line represents the sum of the averaging kernel at each altitude.

profile varies between $50 \%$ and $120 \%$. However, averaging reduces the errors considerably and provides value given the current paucity of measurements in the UTLS. In this paper we examine the average global behaviour and the random retrieval error (i.e. in Fig. 7) is in effect much lower than this due to number of individual profiles.

\subsection{Retrieval characterisation}

We have used one month of high-resolution MIPAS data to investigate the global-average distribution of acetone in the UTLS for August 2003. Previous work by Singh et al. (1994) estimates that $21 \%$ of the acetone source is due to direct biogenic emissions and we chose to look at August 2003 since this period represents the end-point of the Northern Hemisphere time of high plant activity. August also encapsulates the Central African biomass burning season which is another direct source of acetone to the atmosphere (Singh et al., 1994).

To determine the sensitivity of MIPAS spectra to changes in acetone VMRs in the UT, it is vital to look at the averaging kernels of the retrieval. Figure 3 shows an example of a typical mid-latitude averaging kernel (in $\log (\mathrm{VMR})$ ) for August, with the highest sensitivity to the measurements in the UT (high averaging kernel value) and a vertical resolution (at full-width half maximum) of around $3 \mathrm{~km}$. As acetone abundances decrease with increasing altitude into the LS (e.g. Elias et al., 2011), the corresponding averaging kernels tend to zero at higher levels and may also show some sensi- tivity to the adjacent layer below. The vertical resolution of $18 \mathrm{~km}$ retrievals is generally no better than $6 \mathrm{~km}$ with a larger a priori influence. In Fig. 3, the areas of the $430 \mathrm{hPa}, 281 \mathrm{hPa}$ and $172 \mathrm{hPa}$ kernels is between 0.7 and 0.8 , indicating that the retrievals are largely free of a priori bias.

\section{Results}

\subsection{Acetone sensitivity in MIPAS spectra}

In this section we investigate the sensitivity of the retrieval microwindow to acetone. We study examples of acetone retrievals with a variety of volume mixing ratios and investigate whether the MIPAS spectra can be simulated just as well by including or neglecting acetone in the simulations. We also check the effect of the continuum retrieval and whether the improvement of fit is due to the continuum retrieval alone. Although we retrieve acetone from a small microwindow $\left(1216.75 \mathrm{~cm}^{-1}\right.$ to $\left.1217.5 \mathrm{~cm}^{-1}\right)$ we extend the spectral range shown here to investigate the robustness of the fit parameters over a wider range. We look at three particular scenarios and report the improvement achieved for: (1) significantly enhanced - Fig. 4a-b, (2) enhanced - Fig. 4c-d and (3) background - Fig. $4 \mathrm{e}-\mathrm{f}$.

It is shown for all three cases that the residual fit using the jointly-retrieved acetone and continuum in the simulations (Fig. $4 \mathrm{a}, \mathrm{c}, \mathrm{e}$ ) is within the $20 \mathrm{nW} /\left(\mathrm{cm}^{2} \mathrm{sr} \mathrm{cm}^{-1}\right)$ MIPAS NESR reported by Kleinert et al. (2007). The fit is worsened considerably when only the continuum is considered in the simulation, particularly for the highest acetone VMR, where differences of up to $60 \mathrm{nW} /\left(\mathrm{cm}^{2} \mathrm{srcm}^{-1}\right)$ or $80 \%$ of the measured radiance are found. Even in the background case, a $10 \%$ improvement of fit is achieved (Fig. 4f) when retrieved acetone is included although the overall sensitivity to acetone in the spectrum has decreased. We also look at the correlation (not shown) between retrieved acetone and $\mathrm{CH}_{4}$ both globally and regionally and see no correlation between the results suggesting that we are successfully fitting acetone and not $\mathrm{CH}_{4}$.

We observe a normal distribution to the $185 \mathrm{hPa}$ residuals (Fig. 5), with no systematic bias due to poor retrieval of an interfering gas, for example. The calculated standard deviation of these data is $14 \mathrm{nW} /\left(\mathrm{cm}^{2} \mathrm{srcm}^{-1}\right)$, well within the reported NESR indicating an excellent quality of fit. Of the 26699 MIPAS scans available for August 2003, the $277 \mathrm{hPa}$ level data have a very high convergence success rate $(97.3 \%$ of the $32 \%$ of data classed as cloud-free). At the $185 \mathrm{hPa}$ level, the rate is even higher, increasing to $99.9 \%$ of the $59 \%$ of cloud-free data points.

\subsection{Global distribution of acetone in the upper troposphere and lower stratosphere}

By choosing to study August 2003, we were able to encapsulate many different regimes within the dataset. Fire activity 

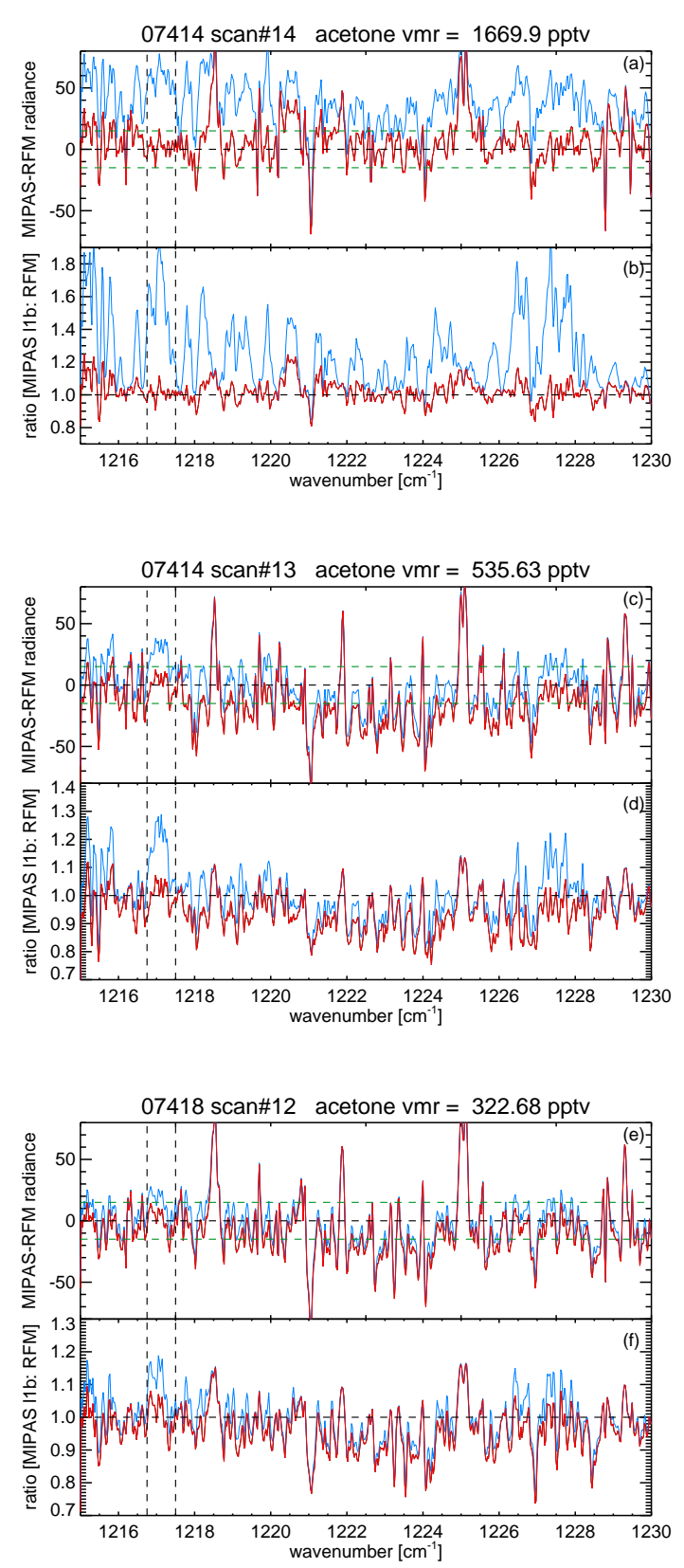

Fig. 4. Radiance residuals (MIPAS radiance - RFM model) and corresponding radiance ratios for data on 1 August 2003 at $12 \mathrm{~km}$ level. The blue lines show data where the RFM simulations included all retrieved gases and retrieved continuum in the acetone microwindow but not including retrieved acetone. The red lines are identical except for the extra inclusion of acetone in the RFM simulations. Scenes were chosen which represent: (1) enhanced acetone VMR (1670 pptv in this scene) - plots (a, b), (2) enhanced acetone levels around the median VMR (536 pptv) - plots (c, d) and (3) background (323 pptv) - plots (e, f). The vertical black dashed lines show the acetone microwindow used and the green horizontal lines the MIPAS NESR. The co-ordinates of the MIPAS measurements shown are (a) $36^{\circ} \mathrm{N}, 37^{\circ} \mathrm{W}$, (c) $30^{\circ} \mathrm{N}, 38^{\circ} \mathrm{W}$ and (e) $26^{\circ} \mathrm{N}$, $137^{\circ} \mathrm{W}$.

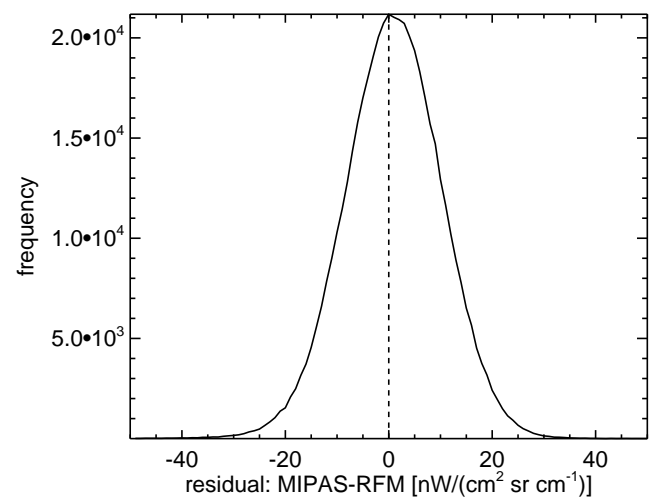

Fig. 5. A histogram of residuals (MIPAS measurements-RFM modelled radiances) from 15578 scans from August 2003 at approximately $185 \mathrm{hPa}$. The standard deviation of our residuals is $14 \mathrm{nW} /\left(\mathrm{cm}^{2} \mathrm{srcm}^{-1}\right)$. Note that the noise equivalent spectral radiance in band B of the MIPAS is below $20 \mathrm{nW} /\left(\mathrm{cm}^{2} \mathrm{srcm}^{-1}\right)$ at $1200 \mathrm{~cm}^{-1}$, (Kleinert et al., 2007). The dashed line represents the zero point in the residual.

082003

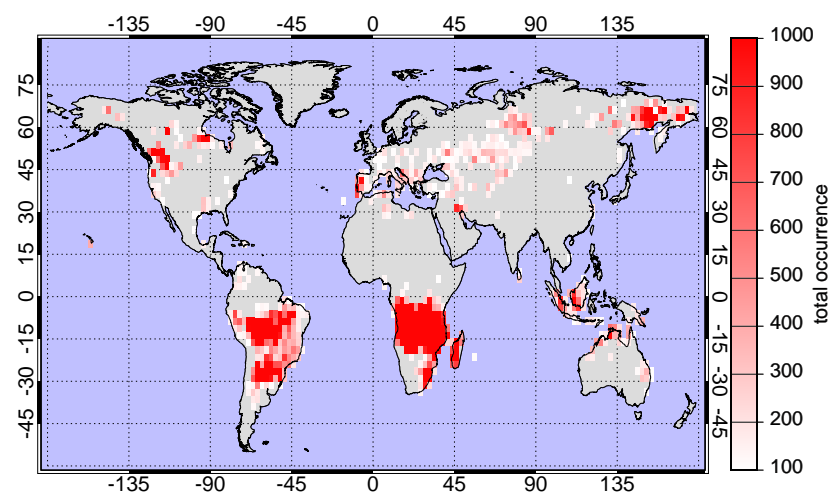

Fig. 6. MODIS fire counts for August 2003 gridded into $2.5^{\circ}$ latitude $\mathrm{x} 2.5^{\circ}$ longitude bins. Fire data points classed with both nominal and high certainty are included.

linked to biomass has a seasonal dependence relying on local dry conditions and availability of fuel. As shown in Fig. 6 the highest frequency of fires occurred over Central-Southern Africa and South America with other centres over Western Canada and North-Eastern Siberia. The fact that August is also during the $\mathrm{NH}$ summer, and hence during a time of high plant activity, introduces another potential source for acetone from the surface.

As discussed previously in Moore and Remedios (2010), we decided against interpolation of data onto pressure levels as interpolation is likely to introduce features which are not present in the dataset. The data are contoured and gridded at $20^{\circ}$ longitude and $10^{\circ}$ latitude resolution. To reduce the bias created by using few data points we decided to remove all areas containing less than 5 data points. 

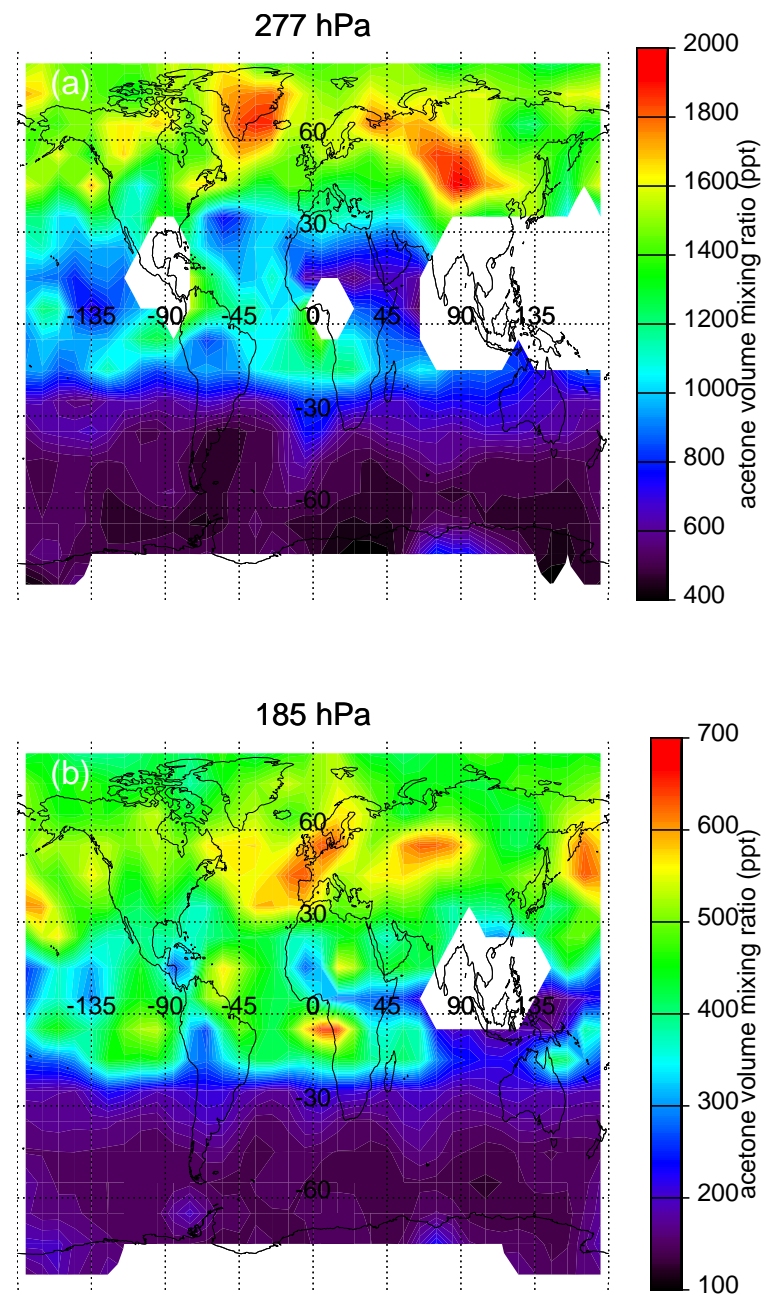

Fig. 7. Global acetone distributions (in units of pptv) at average pressure levels of (a) $277 \mathrm{hPa}$ and (b) $185 \mathrm{hPa}$ for the month of August 2003. White areas are regions where there are less than 5 data points for the month.

From Fig. 7a, b we can clearly identify a distinct interhemispheric difference between the higher volume mixing ratios (VMRs) in the $\mathrm{NH}$ compared to lower VMRs in the Southern Hemisphere (SH) at both $277 \mathrm{hPa}$ and $185 \mathrm{hPa}$. At $277 \mathrm{hPa}$, the highest average acetone VMRs are found over Greenland and Western Siberia (between 1.6 and 2.3 ppbv) and there is clear inter-continental transport (see wind fields in Fig. 8). At $277 \mathrm{hPa}$ we observe a large variability in the NH UT data of up to $1200 \mathrm{pptv}$ poleward of $30^{\circ} \mathrm{N}$. This change occurs within areas as small as 30 latitude-longitude degrees and is most pronounced over the North Atlantic Ocean. This high variability is consistent with the findings of Elias et al. (2011) who noted that the summer acetone VMRs in aircraft data can vary by more than 1000 pptv within only 5 latitude-longitude degrees with a standard deviation for measurements (chiefly over South-East Asia) of up to $40 \%$. The highest values are in the Northern Hemisphere over boreal all August 2003, 189.147 hPa

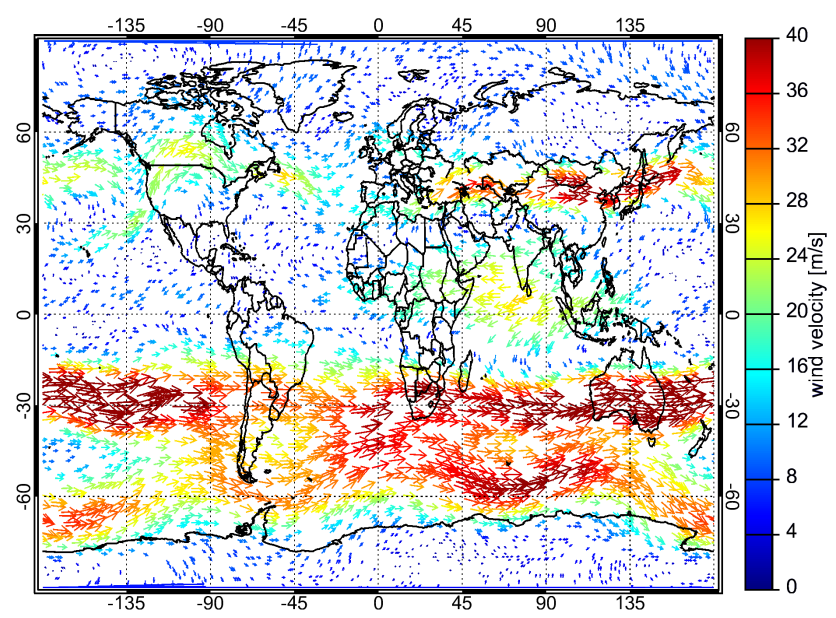

Fig. 8. Monthly-average wind field for August 2003 derived from ECMWF data. Data are taken on level $29(187 \mathrm{hPa})$. Each wind vector is coloured according to average wind velocity.

North America, Greenland and Siberia (between $1.6 \mathrm{ppbv}$ and $2.3 \mathrm{ppbv}$ ), with corresponding enhancements between Central Africa and South America (1.0 ppbv to $1.4 \mathrm{ppbv}$ ). These regions clearly show the effects of inter-continental transport and biomass burning (see later in this section), with the possibility of large biogenic sources coupled with convection giving rise to strong signatures. Model studies would clearly be useful but agreement between aircraft data and models is only fair in the studies of Elias et al. (2011). For example, in the Europe-Mediterranean range their model runs and data disagreed by up to $800 \mathrm{pptv}$, with data showing strikingly high values of acetone over Europe in summer. Their values of typically greater than 1000 pptv are consistent with our results at $277 \mathrm{hPa}$ coupled with enhancements observed more directly at $185 \mathrm{hPa}$ for this region.

At both $277 \mathrm{hPa}$ and $185 \mathrm{hPa}$, there are clear biogenic or biomass burning influences in the data over Central Africa (up to $700 \mathrm{pptv}$ ), which extends westward across the South Atlantic Ocean towards South America and eastward towards Australia. Although the HYSPLIT trajectory calculations in Fig. 9, suggest acetone produced over Africa and South America can be rapidly transported to Australia on timescales less than five-days, the evidence in the measurements shows that VMRs decrease rapidly along the track across the Indian Ocean and are $50 \%$ lower over Australia compared to the African data. Mixing or vertical transport are two possible mechanisms for this lower acetone and cannot be shown by the 2-D HYSPLIT model data. We cannot discount local sources over Indonesia or Australia itself to explain the higher acetone observed over the Australian East coast (see fire map in Fig. 6).

Globally, we see no evidence of higher VMRs at $185 \mathrm{hPa}$ compared to $277 \mathrm{hPa}$, with the average $\mathrm{NH}$ mid-latitude 


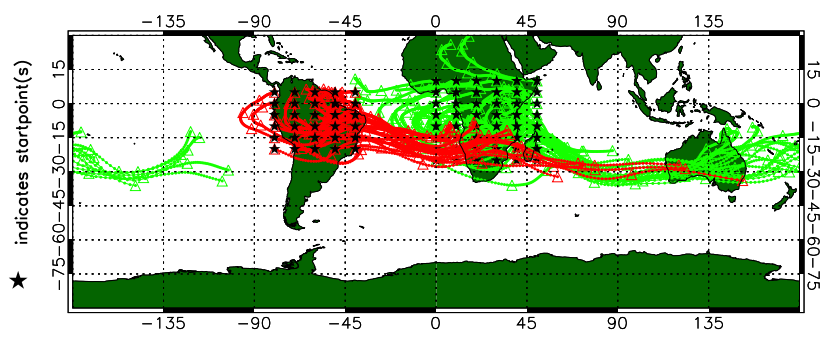

Fig. 9. HYSPLIT 5-day forward trajectories originating from Central Africa (green) and Amazon (red) regions on 1 August 2003 at $185 \mathrm{hPa}$. The regions were chosen based on MODIS fire activity for this month in Fig. 6

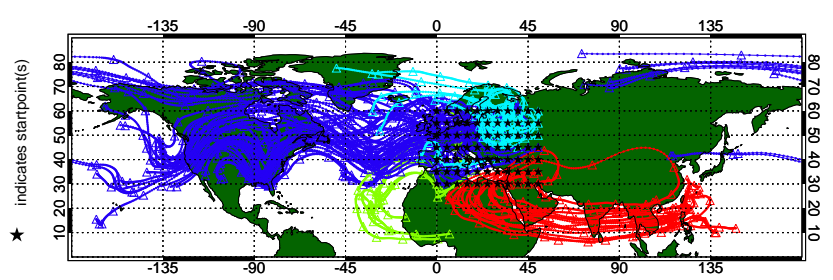

Fig. 10. HYSPLIT 10-day backward trajectories initiated from Europe on 15 August 2003 at $185 \mathrm{hPa}$. Pathways are influenced by four areas coloured by: (1) Dark blue - North America, (2) Red South-East Asia, (3) Green - Northern Africa and (4) Light blue Europe.

zonal VMR $\left(20^{\circ} \mathrm{N}\right.$ to $\left.65^{\circ} \mathrm{N}\right)$ decreasing by $67 \%$ from 1096 pptv to $360 \mathrm{pptv}$. In the $\mathrm{SH}$, the westerly winds are stronger with values in some regions of over $40 \mathrm{~m} \mathrm{~s}^{-1}$ in the average. There is only a very small zonal component in the mean, which explains the lack of mixing polewards of $25^{\circ} \mathrm{S}$ and where the acetone VMR gradient changes by over 250 pptv in just 10 degrees of latitude.

The region of higher acetone VMRs over Europe at $185 \mathrm{hPa}$ appears to have a variety of origins depending on the location in the UT over Europe. Running HYSPLIT 10day back-trajectories from 15 August 2003, the majority of pathways, $56 \%$, have tracked over North America in the past 10-days, very consistent with the wind fields in Fig. 8, although a significant fraction, $25 \%$, originate from Southern Asia. Similar significant transport from North America and Asia into the region was also determined by Scheeren et al. (2003) during the Mediterranean INtensive Oxidant Study (MINOS). The Scheeren et al. (2003) study using the German Aerospace Organisation Falcon Aircraft investigated long-range transport of pollutants and during August 2001 into Europe. Although pathways were similar, they measured slightly higher average VMRs from North America/Atlantic air (957 pptv) and South Asia (1093 pptv) compared to the 650 pptv maxima we observe from MIPAS. The MIPAS data, however, are comparable to the GEOS-CHEM mid-summer model data of 500 pptv at the tropopause presented in Jacob et al. (2002).

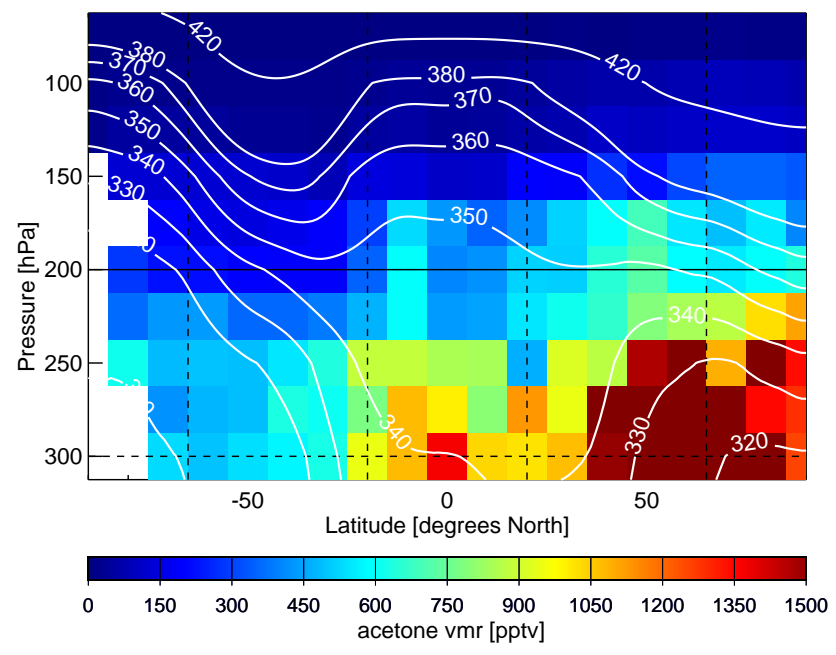

Fig. 11. The zonal acetone distribution of acetone (units of pptv) as a function of pressure for August 2003. Data are averaged into $10^{\circ}$ latitude $\times 25 \mathrm{hPa}$ pressure boxes. White lines indicate potential temperature $(\theta)$ levels in Kelvin. White squares indicate regions where there are fewer than ten clear data points for the month.

In conjunction with ECMWF analyses of potential temperature, we show the monthly average zonal distribution of acetone in the UTLS (Fig. 11) gridded into 10 degree latitude $\times 25 \mathrm{hPa}$ pressure co-ordinates. The hemispheric gradient shown in Fig. 7 is clearly seen here too with the average highest VMRs poleward of $40^{\circ} \mathrm{N}$ and at pressures greater than $210 \mathrm{hPa}$. As the MIPAS acetone data have a $3 \mathrm{~km}$ to $4 \mathrm{~km}$ vertical resolution in the UT, it is very difficult to directly infer acetone mixing between the troposphere and stratosphere from the data presented. The only small enhancement between $380 \mathrm{~K}$ and $420 \mathrm{~K}$ is observed at NH latitudes, consistent with Sprung and Zahn (2010). The tropical mid-troposphere data shows a slight enhancement of acetone, with VMRs ranging between 500 and $1500 \mathrm{pptv}$, but there is no evidence of acetone VMRs exceeding $700 \mathrm{pptv}$ in the tropical UT between $200 \mathrm{hPa}$ and the $380 \mathrm{~K}$ theta surface.

It is interesting to examine 5-day averages and Fig. 12 shows a plot for $277 \mathrm{hPa}$. There is a clear decrease in acetone VMRs poleward of $45^{\circ} \mathrm{N}$ (Fig. 12) with a difference of over 300 pptv between the start and end of August 2003. Unlike the $\mathrm{NH}$, there is a much lower variability in the tropics and poleward of $45^{\circ} \mathrm{S}$ suggesting a more consistent source in these regions over the whole month.

\subsection{Acetone-carbon monoxide ratios}

It has been shown by de Reus et al. (2003) that the VMRs of acetone and carbon monoxide (CO) show a linear relationship in air parcels influenced by anthropogenic emissions, although no significant correlation is observed over areas such as tropical rainforest where there is a large direct and indirect biogenic emission of acetone. Previous work with acetylene 


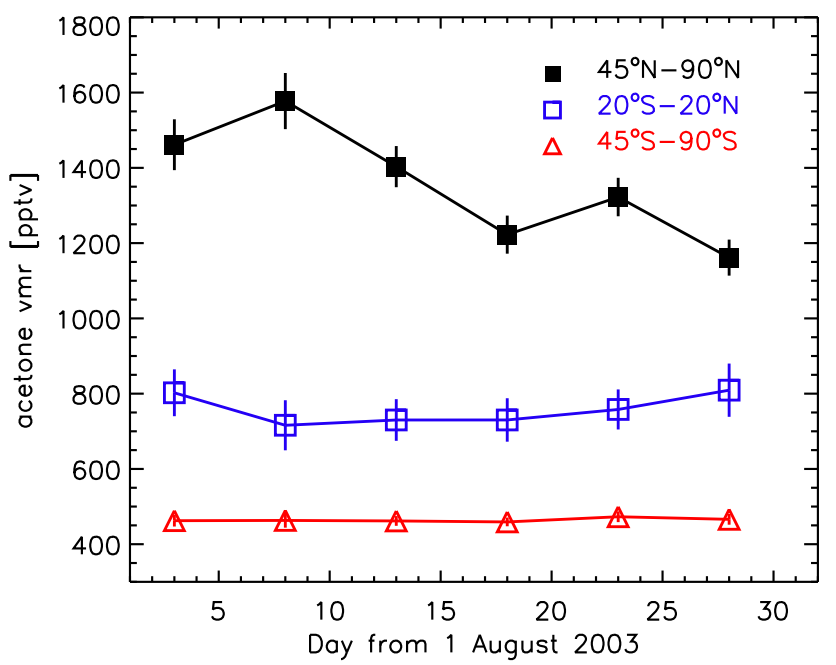

Fig. 12. Daily-average acetone volume mixing ratios for three regions at an average pressure level of $277 \mathrm{hPa}$; (a) $45^{\circ} \mathrm{N}$ to $90^{\circ} \mathrm{N}$, (b) $20^{\circ} \mathrm{S}$ to $20^{\circ} \mathrm{N}$ and (c) $45^{\circ} \mathrm{S}$ to $90^{\circ} \mathrm{S}$.

$\left(\mathrm{C}_{2} \mathrm{H}_{2}\right)$, another biomass burning tracer, shows a strong relationship between $\mathrm{C}_{2} \mathrm{H}_{2}$ and $\mathrm{CO}$ (Parker et al., 2011; Wang et al., 2004) and both papers show that the $\mathrm{C}_{2} \mathrm{H}_{2} / \mathrm{CO}$ ratio is a good indicator of the relative age of the air mass and the amount of processing it has undergone. For the satellite data shown here, it is not possible to separate air masses very easily in order to examine correlations. In this section we examine acetone(pptv)/CO(ppbv) ratios. Similar to Parker et al. (2011) we use the $300 \mathrm{hPa}$ MOPITT (Measurement Of Pollution In The Troposphere) Level 2 version 3 data for comparison to the MIPAS acetone.

The two different viewing geometries of MIPAS (limb) and MOPITT (nadir) also need to be considered in the interpretation. The sharp averaging kernels of MIPAS acetone (Fig. 3) are very different to the broad tropospheric averaging kernels of the MOPITT in the troposphere (Deeter et al., 2003). Typically the MOPITT CO $150 \mathrm{hPa}$ and $250 \mathrm{hPa}$ retrievals are sensitive to CO between $400 \mathrm{hPa}$ and $100 \mathrm{hPa}$ with a slight variation between day and night measurements. This introduces an uncertainty into the ratios of typically $10 \%$.

Work by de Reus et al. (2003) has shown the acetone/CO relationship is linear in free tropospheric air masses with ratios of between $21-25 \mathrm{pptv}_{\mathrm{ppbv}}{ }^{-1}$ observed in air masses influenced by anthropogenic emissions and decreasing to $13-16 \mathrm{pptv}_{\mathrm{ppbv}}{ }^{-1}$ in anthropogenically influenced marine boundary layer air, this difference being due to ocean sources of acetone in relatively clean air (lower CO). Lowermost stratosphere data have a much smaller ratio still $\left(\sim 5 \mathrm{pptv} \mathrm{ppbv}^{-1}\right)$ due to the longer photochemical lifetime of CO compared to acetone in the lower stratosphere. Scheeren et al. (2003) determine that the signature of the linear relationship between acetone and $\mathrm{CO}$ is robust and does not

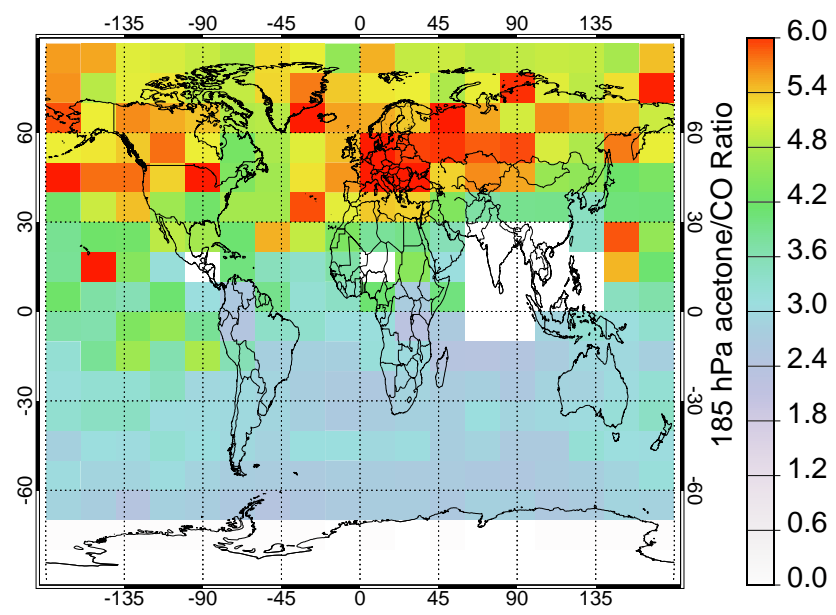

Fig. 13. $185 \mathrm{hPa}$ MORSE acetone/ $150 \mathrm{hPa}$ MOPITT CO ratio for August 2003 calculated from the $10^{\circ}$ latitude $\times 20^{\circ}$ longitude globally gridded data (in units of pptv ppbv ${ }^{-1}$ ). Ratios are only shown where more than ten cloud-free MIPAS data points exist in the box.

change significantly in air masses with a lifetime of up to 15 days. However, Elias et al. (2011) establish some variations in the relationship, particularly for Europe compared to China.

In Fig. 13, we plot the ratio of acetone/CO. Highest ratios (between $5.5 \mathrm{pptv} p p b v^{-1}$ and $7 \mathrm{pptv} p p b v^{-1}$ ) are observed over Europe and in good agreement with the values in the lowermost stratosphere during MINOS. This campaign focussed specifically on anthropogenic pollution transport, compared to monthly averages in our analysis, which explains why the MINOS values were slightly higher. It is still clear, however, that the ratio remains high over Europe throughout the whole of August, where mixing and chemistry leads to strong heterogeneity in relationships and confirming the high ratios at relatively modest values of $\mathrm{CO}$ observed by Elias et al. (2011).

Tropical acetone/CO ratios are lower than the NH values by between $2.5 \mathrm{pptv} p p b v^{-1}$ and $3.5 \mathrm{pptv}_{\mathrm{ppbv}}{ }^{-1}$. Over the tropical Amazon rainforest, measurements presented by de Reus et al. (2003) determine that the correlation between acetone/CO is not always observed, concluding that this is due to the increased importance of the biogenic source of acetone here compared to other regions combined and lower $\mathrm{CO}$ (mostly of anthropogenic origin). We measure acetone VMRs of up to 700 pptv over central Africa (Fig. 7) but the ratio results infer that tropical biomass burning emissions of $\mathrm{CO}$ are large enough to depress the acetone/CO ratio. We have shown (Fig. 6) that both the Southern Amazon and Central Africa have a very large number of fires during August 2003 and is the most likely cause of enhanced CO and the direct effect we observe on the ratios. Finally, SH ratios are between 1.0 and 3.0. 


\section{Conclusions}

Acetone $\left(\mathrm{C}_{3} \mathrm{H}_{6} \mathrm{O}\right)$ is present ubiquitously in the troposphere from a variety of sources including biomass burning, direct biogenic emissions and anthropogenic emission. The largest source, however, is thought to be from secondary formation via oxidation of precursor hydrocarbons such as propane and isobutene. The gas is a major source of hydrogen oxide radicals and peroxyacetyl nitrate (PAN) in the upper troposphere.

This study has presented the first global observations of acetone in the upper troposphere (UT) from MIPAS spectral measurements during August 2003. Data are presented over the $9 \mathrm{~km}$ to $15 \mathrm{~km}$ altitude range, approximately $300 \mathrm{hPa}$ to $150 \mathrm{hPa}$ in pressure terms. Total errors on single profiles are calculated to be below $40 \%$ at pressures between $250 \mathrm{hPa}$ and $350 \mathrm{hPa}$ although tropical retrievals are affected strongly by water vapour and errors are around $80 \%$. At pressures below this the random error component rapidly increases. Averaging kernels generally show upper tropospheric measurements have a vertical resolution of between $3 \mathrm{~km}$ and $4 \mathrm{~km}$ which increases to $6 \mathrm{~km}$ in the lower stratosphere. Due to the relatively broad vertical resolution in the lower stratosphere, we are not able to infer mixing of tropospheric acetone into the stratosphere.

The global distribution of acetone has been determined as a function of latitude and exhibits distinct inter-hemispheric differences with the highest average VMRs found over Greenland and Western Siberia at $277 \mathrm{hPa}$ of between $1.6 \mathrm{ppbv}$ and $2.3 \mathrm{ppbv}$. High acetone VMRs were also found in the tropics, particularly between Central Africa and South America where abundances ranged between $1.0 \mathrm{ppbv}$ and $1.4 \mathrm{ppbv}$. Acetone over Europe originated from a variety of source regions with HYSPLIT trajectory calculations showing the majority of pathways originated from above North America (56\%) with a significant fraction (25\%) flowing from South-East Asia and was comparable to previous data measured during MINOS.

Ratios of acetone(pptv)/CO(ppbv) indicate the relative age of the air mass and the amount of processing the air mass has undergone. At $185 \mathrm{hPa}$, we observe ratios which vary between 3 pptv ppbv ${ }^{-1}$ and 7 pptv ppbv $^{-1}$ showing we observe a mixture of stratospheric and tropospheric air. Highest ratios were observed over Europe (5.5 pptv ppbv ${ }^{-1}$ to $7.0 \mathrm{pptv}^{\mathrm{ppbv}}{ }^{-1}$ ) and were in excellent agreement with previous findings by de Reus et al. (2003) and our results confirm a strong enhancement of UT acetone over Europe relative to $\mathrm{CO}$. Tropical acetone(pptv)/CO(ppbv) ratios were much lower at between $2.5 \mathrm{pptv} p p b v^{-1}$ to $3.5 \mathrm{pptv}_{\mathrm{ppbv}}{ }^{-1}$, which is due to the increased importance of biogenic source (with lower $\mathrm{CO}$ ) compared to biomass burning alone.

These new, global, measurements of acetone from satellite data will provide valuable input towards the modelling of chemical processes in the upper troposphere. The large discrepancies between aircraft and model data noted by Elias et al. (2011) can only be improved by the use of MIPAS acetone helping to further constrain models to improve understanding of acetone chemistry in the UT. Interpretation of the causes of the large summer-time variability and understanding Arctic chemical processes, where in-situ observations are sparse, are critical areas that can be improved by better data availability. A likely progression of this study is to determine the seasonal cycle of acetone in the UT across different years and compare these data to a chemical transport model.

Acknowledgements. David Moore was funded by the UK NERC National Centre for Earth Observation (NCEO). The authors wish to thank the European Space Agency for access to MIPAS data under CUTLSOM (AO-357). The authors would also like to thank Anu Dudhia for providing us with the Oxford reference forward model (RFM) and the MIPAS Orbital Retrieval using Sequential Estimation (MORSE) scheme used in this study. The MOPITT Level 2 (L2) Version 3 data and MODIS fire data were obtained from the NASA Langley Research Center Atmospheric Science Data Center. The authors also gratefully acknowledge the NOAA Air Resources Laboratory (ARL) for the provision of the HYSPLIT transport and dispersion model used in this publication. We finally thank the European Centre for Medium-Range Weather Forecasts (ECMWF) for Operational Analysis data, [Internet]. Data are available from http://badc.nerc.ac.uk/view/badc.nerc.ac. uk__ATOM_dataent_ECMWF-OP.

Edited by: A. Richter

\section{References}

Arnold, F. A., Schneider, J., Gollinger, K., Schlager, H., Schulte, P., Hagen, D. E., Whitefield, P. D., and van Velthoven, P.: Observation of upper tropospheric sulfur dioxide- and acetone pollution: Potential implications for hydroxyl radical and aerosol formation, Geophys. Res. Lett., 24, 57-60, 1997.

Brenninkmeijer, C. A. M., Crutzen, P., Boumard, F., Dauer, T., Dix, B., Ebinghaus, R., Filippi, D., Fischer, H., Franke, H., Frieß, U., Heintzenberg, J., Helleis, F., Hermann, M., Kock, H. H., Koeppel, C., Lelieveld, J., Leuenberger, M., Martinsson, B. G., Miemczyk, S., Moret, H. P., Nguyen, H. N., Nyfeler, P., Oram, D., O'Sullivan, D., Penkett, S., Platt, U., Pupek, M., Ramonet, M., Randa, B., Reichelt, M., Rhee, T. S., Rohwer, J., Rosenfeld, K., Scharffe, D., Schlager, H., Schumann, U., Slemr, F., Sprung, D., Stock, P., Thaler, R., Valentino, F., van Velthoven, P., Waibel, A., Wandel, A., Waschitschek, K., Wiedensohler, A., Xueref-Remy, I., Zahn, A., Zech, U., and Ziereis, H.: Civil Aircraft for the regular investigation of the atmosphere based on an instrumented container: The new CARIBIC system, Atmos. Chem. Phys., 7, 4953-4976, doi:10.5194/acp-7-4953-2007, 2007.

Burgess, A. B., Grainger, R. G., Dudhia, A., Payne, V. H., and Jay, V. L.: MIPAS measurement of sulphur hexafluoride $\left(\mathrm{SF}_{6}\right)$, Geophys. Res. Lett., 31, L07809, doi:10.1029/2003GL019143, 2004.

Collins, W. J., Stevenson, D. S., Johnson, C. E., and Derwent, R. G.: Role of convection in determining the budget of odd hydrogen in the upper troposphere, J. Geophys. Res., 104, 26927-26941, 1999. 
Cortesi, U., Lambert, J. C., De Clercq, C., Bianchini, G., Blumenstock, T., Bracher, A., Castelli, E., Catoire, V., Chance, K. V., De Mazire, M., Demoulin, P., Godin-Beekmann, S., Jones, N., Jucks, K., Keim, C., Kerzenmacher, T., Kuellmann, H., Kuttippurath, J., Iarlori, M., Liu, G. Y., Liu, Y., McDermid, I. S., Meijer, Y. J., Mencaraglia, F., Mikuteit, S., Oelhaf, H., Piccolo, C., Pirre, M., Raspollini, P., Ravegnani, F., Reburn, W. J., Redaelli, G., Remedios, J. J., Sembhi, H., Smale, D., Steck, T., Taddei, A., Varotsos, C., Vigouroux, C., Waterfall, A., Wetzel, G., and Wood, S.: Geophysical validation of MIPAS-ENVISAT operational ozone data, Atmos. Chem. Phys., 7, 4807-4867, doi:10.5194/acp-7-4807-2007, 2007.

Crutzen, P. J., Williams, J., Pöschl, U., Hoor, P., Fischer, H., Warneke, C., Holzinger, R., Hansel, A., Lindinger, W., Scheeren, B., and Lelieveld, J.: High spatial and temporal resolution measurements of primary organics and their oxidation products over the tropical rainforests of Surinam, Atmos. Environ., 34, 11611165, 2000.

Deeter, M. N., Emmons, L. K., Francis, G. L., Edwards, D. P., Gille, J. C., Warner, J. X., Khattatov, B., Ziskin, D., Lamarque, J.-F., Ho, S.-P., Yudin, V., Attié, J.-L., Packman, D., Chen, J., Mao, D., and Drummond, J. R.: Operational carbon monoxide retrieval algorithm and selected results for the MOPITT instrument, J. Geophys. Res, 108, 4399, doi:10.1029/2002JD003186, 2003.

Edwards, D. P.: GENLN2: A general line-by-line atmospheric transmittance and radiance model, version 3.0 description and users guide, NCAR/TN-367-STR, national Center for Atmospheric Research, Boulder, CO, USA, 1992.

Elias, T., Szopa, S., Zahn, A., Schuck, T., Brenninkmeijer, C., Sprung, D., and Slemr, F.: Acetone variability in the upper troposphere: analysis of CARIBIC observations and LMDz-INCZ chemistry-climate model simulations, Atmos. Chem. Phys., 11, 8053-8074, doi:10.5194/acp-11-8053-2011, 2011.

Fischer, H. and Oelhaf, H.: Remote sensing of vertical profiles of atmospheric trace constituents with MIPAS limb-emission spectrometers, Appl. Optics, 35, 2787-2796, 1996.

Fischer, H., Birk, M., Blom, C., Carli, B., Carlotti, M., von Clarmann, T., Delbouille, L., Dudhia, A., Ehhalt, D., Endemann, M., Flaud, J. M., Gessner, R., Kleinert, A., Koopman, R., Langen, J., López-Puertas, M., Mosner, P., Nett, H., Oelhaf, H., Perron, G., Remedios, J., Ridolfi, M., Stiller, G., and Zander, R.: MIPAS: an instrument for atmospheric and climate research, Atmos. Chem. Phys., 8, 2151-2188, doi:10.5194/acp-8-2151-2008, 2008.

Folkins, I. and Chatfield, R.: Impact of acetone on ozone production and $\mathrm{OH}$ in the upper troposphere at high $\mathrm{NO}_{\mathrm{x}}$, J. Geophys. Res., 105, 11585-11599, 2000.

Gierczak, T., Burkholder, J. B., Bauerle, S., et al.: Photochemistry of acetone under tropospheric conditions, Chem. Phys., 231, 229-244, 1998.

Harrison, J. J., Humpage, N., Allen, N. D. C., Waterfall, A. M., Bernath, P. F., and Remedios, J. J.: Mid-infrared absorption cross sections for acetone (propanone), J Quant. Spectrosc. Ra., 112, 457-464, 2011.

Hauck, G. and Arnold, F.: Improved positive-ion composition measurements in the upper troposphere and lower stratosphere and the detection of acetone, Nature, 311, 547-550, 1984.

Hoffmann, L., Spang, R., Kaufmann, M., and Riese, M.: Retrieval of CFC-11 and CFC-12 from ENVISAT MIPAS observations by means of rapid radiative transfer calculations, Adv. Space Res.,
36, 915-921, 2005.

Holton, J. R., Haynes, P. H., McIntyre, M. E., Douglass, A. R., Rood, R. B., and Pfister, L.: Stratosphere-troposphere exchange, Rev. Geophys., 33, 403-439, 1995.

Horowitz, L. W., Walters, S., Mauzerall, D. L., Emmons, L. K., Rasch, P. J., Granier, C., Tie, X., Lamarque, J.-F., Schultz, M. G., Tyndall, G. S., Orlando, J. J., and Brasseur, G. P.: A global simulation of tropospheric ozone and related tracers: Description and evaluation of MOZART, version 2, J. Geophys. Res., 108, 4784, doi:10.1029/2002JD002853, 2003.

Jacob, D. J., Field, B. D., Jin, E. M., Bey, I., Li, Q., Logan, J., Yantosca, R., and Singh, H.: Atmospheric budget of acetone, J. Geophys. Res., 107, 4100, doi:10.1029/2001JD000694, 2002.

Jaegle, L., Jacob, D. J., Wennberg, P. O., Spivakovsky, C. M., Hanisco, T. F., Lanzendorf, E. J., Hintsa, E. J., Fahey, D. W., Keim, E. R., Proffitt, M. H., Atlas, E. L., Flocke, F., Schauffler, S., McElroy, C. T., Midwinter, C., Pfister, L., and Wilson, J. C.: Observed $\mathrm{OH}$ and $\mathrm{HO}_{2}$ in the upper troposphere suggest a major source from convective injection of peroxides, Geophys. Res. Lett, 24, 3181-3184, 1997.

Jaegle, L., Jacob, D. J., Brune, W. H., and Wennberg, P. O.: Chemistry of $\mathrm{HO}_{\mathrm{x}}$ radicals in the upper troposphere, Atmos. Environ., 35, 469-489, 2001.

Kleinert, A., Aubertin, G., Perron, G., Birk, M., Wagner, G., Hase, F., Nett, H., and Poulin, R.: MIPAS Level 1B algorithms overview: operational processing and characterization, Atmos. Chem. Phys., 7, 1395-1406, doi:10.5194/acp-7-13952007, 2007.

Knop, G. and Arnold, F.: Stratospheric trace gas detection using a new alloon-borne acims method: acetonitrile, acetone, and nitric acid, Geophys. Res. Lett., 14, 1262-1265, 1987.

Lahoz, W., Geer, A., Swinbank, R., Jackson, D., Thornton, H., Dethof, A., and Fonteyn, D.: Modelling and assimilation: evaluation of MIPAS water vapour, Proceedings of the ACVE-2 meeting, 3-7 May, Frascati, Italy, 2004.

McKeen, S. A., Gierczak, T., Burkholder, J. B., Wennberg, P. O., Hanisco, T. F., Keim, E. R., Gao, R.-S., Liu, S. C., Ravishankara, A. R., and Fahey, D. W.: The photochemistry of acetone in the upper troposphere: a source of odd-hydrogen radicals, Geophys. Res. Lett., 24, 3177-3180, 1997.

Moore, D. P. and Remedios, J. J.: Seasonality of Peroxyacetyl nitrate (PAN) in the upper troposphere and lower stratosphere using the MIPAS-E instrument, Atmos. Chem. Phys., 10, 6117-6128, doi:10.5194/acp-10-6117-2010, 2010.

Muller, J.-F. and Brasseur, G.: Sources of upper tropospheric $\mathrm{HO}_{\mathrm{x}}$ : a three-dimensional study, J. Geophys. Res., 104, 1705-1715, 1999.

Parker, R. J., Remedios, J. J., Moore, D. P. and Kanawade, V. P.: Acetylene $\mathrm{C} 2 \mathrm{H} 2$ retrievals from MIPAS data and regions of enhanced upper tropospheric concentrations in August 2003, Atmos. Chem. Phys., 11, 10243-10257, doi:10.5194/acp-1110243-2011, 2011.

Payan, S., Camy-Peyret, C., Oelhaf, H., Wetzel, G., Maucher, G., Keim, C., Pirre, M., Huret, N., Engel, A., Volk, M. C., Kuellmann, H., Kuttippurath, J., Cortesi, U., Bianchini, G., Mencaraglia, F., Raspollini, P., Redaelli, G., Vigouroux, C., De Mazière, M., Mikuteit, S., Blumenstock, T., Velazco, V., Notholt, J., Mahieu, E., Duchatelet, P., Smale, D., Wood, S., Jones, N., Piccolo, C., Payne, V., Bracher, A., Glatthor, N., 
Stiller, G., Grunow, K., Jeseck, P., Te, Y., and Butz, A.: Validation of version-4.61 methane and nitrous oxide observed by MIPAS, Atmos. Chem. Phys., 9, 413-442, doi:10.5194/acp-9413-2009, 2009.

Press, W. H., Flannery, B. P., Teukolsky, S. A., and Vetterling, W. T.: Numerical Recipes in FORTRAN 77: The Art of Scientific Computing, version 1, Cambridge University Press, 1992.

Raspollini, P., Belotti, C., Burgess, A., Carli, B., Carlotti, M., Ceccherini, S., Dinelli, B. M., Dudhia, A., Flaud, J.-M., Funke, B., Höpfner, M., López-Puertas, M., Payne, V., Piccolo, C., Remedios, J. J., Ridolfi, M., and Spang, R.: MIPAS level 2 operational analysis, Atmos. Chem. Phys., 6, 5605-5630, doi:10.5194/acp6-5605-2006, 2006.

Remedios, J. J., Allen, G., Waterfall, A. M., Oelhaf, H., Kleinert, A., and Moore, D. P.: Detection of organic compound signatures in infra-red, limb emission spectra observed by the MIPASB2 balloon instrument, Atmos. Chem. Phys., 7, 1599-1613, doi:10.5194/acp-7-1599-2007, 2007a.

Remedios, J. J., Leigh, R. J., Waterfall, A. M., Moore, D. P., Sembhi, H., Parkes, I., Greenhough, J., Chipperfield, M. P., and Hauglustaine, D.: MIPAS reference atmospheres and comparisons to V4.61/V4.62 MIPAS level 2 geophysical data sets, Atmos. Chem. Phys. Discuss., 7, 9973-10017, doi:10.5194/acpd7-9973-2007, 2007b.

de Reus, M., Fischer, H., Arnold, F., de Gouw, J., Holzinger, R., Warneke, C., and Williams, J.: On the relationship between acetone and carbon monoxide in different air masses, Atmos. Chem. Phys., 3, 1709-1723, doi:10.5194/acp-3-1709-2003, 2003.

Ridolfi, M., Blum, U., Carli, B., Catoire, V., Ceccherini, S., Claude, H., De Clercq, C., Fricke, K. H., Friedl-Vallon, F., Iarlori, M., Keckhut, P., Kerridge, B., Lambert, J.-C., Meijer, Y. J., Mona, L., Oelhaf, H., Pappalardo, G., Pirre, M., Rizi, V., Robert, C., Swart, D., von Clarmann, T., Waterfall, A., and Wetzel, G.: Geophysical validation of temperature retrieved by the ESA processor from MIPAS/ENVISAT atmospheric limbemission measurements, Atmos. Chem. Phys., 7, 4459-4487, doi:10.5194/acp-7-4459-2007, 2007.

Rodgers, C.: Inverse methods for atmospheric sounding: theory and practice, World Sci., River Edge, N. J, 2000.

Rothman, L. S., Jacquemart, D., Barbe, A., Chris Benner, D., Birk, M., Brown, L. R., Carleer, M. R., Chackerian Jr., C., Chance, K., Coudert, L. H., Dana, V., Devi, V. M., Gamache, R. R., Goldman, A., Jucks, K. W., Maki, A. G., Massie, S. T., Orphal, J., Perrin, A., Rinsland, C. P., Smith, M. A. H., Tennyson, J., Tolchenov, R. N., Toth, R. A., Vander Auwera, J., Varanasi, P., and Wagner, G.: The HITRAN 2004 molecular spectroscopic database, J. Quant. Spectrosc. Ra., 96, 139-204, 2005.

Scheeren, H. A., Lelieveld, J., Roelofs, G. J., Williams, J., Fischer, H., de Reus, M., de Gouw, J. A., Warneke, C., Holzinger, R., Schlager, H., Klüpfel, T., Bolder, M., van der Veen, C., and Lawrence, M.: The impact of monsoon outflow from India and Southeast Asia in the upper troposphere over the eastern Mediterranean, Atmos. Chem. Phys., 3, 1589-1608, doi:10.5194/acp-31589-2003, 2003.
Singh, H. B., O'Hara, D., Herlth, D., Sachse, W., Blake, D. R., Bradshaw, J. D., Kanakidou, M., and Crutzen, P. J.: Acetone in the atmosphere: distribution, sources and sinks, J. Geophys. Res., 99, 1805-1819, 1994.

Singh, H. B., Kanakidou, M., Crutzen, P. J., and Jacob, D. J.: High concentrations and photochemical fate of oxygenated hydrocarbons in the global troposphere, Nature, 378, 50-54, 1995.

Spang, R., Remedios, J. J., and Barkley, M. P.: Colour indices for the detection and differentiation of cloud types in infrared limb emission spectra, Adv. Space. Res., 33, 1041-1047, 2004.

Spang, R., Remedios, J. J., Kramer, L. J., Poole, L. R., Fromm, M. D., Müller, M., Baumgarten, G., and Konopka, P.: Polar stratospheric cloud observations by MIPAS on ENVISAT: detection method, validation and analysis of the northern hemisphere winter 2002/2003, Atmos. Chem. Phys., 5, 679-692, doi:10.5194/acp-5-679-2005, 2005.

Sprung, D. and Zahn, A.: Acetone in the upper troposphere/lowermost stratosphere measured by the CARIBIC passenger aircraft: Distribution, seasonal cycle, and variability, J. Geophys. Res, 115, D16301, doi:10.1029/2009JD012099,2010.

von Clarmann, T., Glatthor, N., Grabowski, U. Höpfner, M., Kellmann, S., Linden, A., Gizaw Mengistu Tsidu, Milz, M., Steck, T., Stiller, G. P., Fischer, H., and Funke, B.: Global stratospheric $\mathrm{HOCl}$ distributions retrieved from infrared limb emission spectra recorded by the Michelson Interferometer for Passive Atmospheric Sounding (MIPAS), J. Geophys. Res., 111, D05311, doi:10.1029/2005JD005939, 2006.

Wang, T., Wong, C. H., Cheung, T. F., Blake, D. R., Arimoto, R., Baumann, K., Tang, J., Ding, G. A., Yu, X. M., Li, Y. S., Streets, D. G., and Simpson, I. J.: Relationships of trace gases and aerosols and the emission characteristics at Lin'an, a rural site in eastern China, during spring 2001, J. Geophys. Res. Atmos., 109, D19S05, doi:10.1029/2003JD004119, 2004.

Wang, D. Y., Höpfner, M., Blom, C. E., Ward, W. E., Fischer, H., Blumenstock, T., Hase, F., Keim, C., Liu, G. Y., Mikuteit, S., Oelhaf, H., Wetzel, G., Cortesi, U., Mencaraglia, F., Bianchini, G., Redaelli, G., Pirre, M., Catoire, V., Huret, N., Vigouroux, C., De Mazière, M., Mahieu, E., Demoulin, P., Wood, S., Smale, D., Jones, N., Nakajima, H., Sugita, T., Urban, J., Murtagh, D., Boone, C. D., Bernath, P. F., Walker, K. A., Kuttippurath, J., Kleinböhl, A., Toon, G., and Piccolo, C.: Validation of MIPAS $\mathrm{HNO}_{3}$ operational data, Atmos. Chem. Phys., 7, 4905-4934, doi:10.5194/acp-7-4905-2007, 2007.

Waterfall, A. M.: Measurements of organic compounds in the Upper Troposphere using Infrared Remote Sensing, D. Phil., University of Oxford, 2004.

Wennberg, P. O., Hanisco, T. F., Jaeglé, L., Jacob, D. J., Hintsa, E. J., Lanzendorf, E. J., Anderson, J. G., Gao, R.-S., Keim, E. R., Donnelly, S. G., Del Negro, L. A., Fahey, D. W., McKeen, S. A., Salawitch, R. J., Webster, C. R., May, R. D., Herman, R. L., Proffitt, M. H., Margitan, J. J., Atlas, E. L., Schauffler, S. M., Flocke, F., McElroy, C. T., and Bui, T. P.: Hydrogen radicals, nitrogen radicals, and the production of ozone in the middle and upper troposphere, Science, 279, 49-53, 1998. 